\title{
Study the Association of Helicobacter pylori and some of Hepatitis C Virus Patients in Egypt
}

\author{
Soheir S. Abd El-Salam*, Marwa Darwish" and Waleed Elagawy ${ }^{* *}$ \\ Botany Department, Faculty of Science, Benha University, Benha; *Biochemistry \\ Department, Faculty of Science, Suez University, Suez and ${ }^{* *}$ Department of Tropical \\ Medicine, National Hepatology and Tropical Medicine Research Institute Cairo, \\ Egypt.
}

OTH hepatitis $\mathrm{C}$ virus and Helicobacter pylori infections are commonly found in Egypt.
Correlation among Helicobacter pylori and HCV has been assisted.

This work aim was to research H. pylori DNA inside the liver tissue of Egyptian suffers with persistent hepatitis $\mathrm{C}$ and find the relation among HP invasion and $\mathrm{HCV}$.

This prospective study was conducted with 49 participants. Helicobacter pylori Standard Kit (H.pylori) genome is designed for the in vitro H.pylori genomes from liver tissues patients with chronic hepatitis $\mathrm{C}$ quantitatively. A TaqMan ${ }^{\circledR}$ principle was used by the primer and probe. During PCR amplification, primers of bidirectional hybridize to the H.pylori DNA. DNA probe was Labeled with a $5{ }^{\prime}$-dye and a $3{ }^{\prime}$-quencher forms the fluorogenic probe. During PCR amplification, the indicator dye and the quencher are separated and the probe is split. The increase in fluorescence can be detected by PCR platforms.

The bacterial DNA was existed in the liver specimens approximately $44.9 \%$ of patients. The DNA of bacteria in hepatic tissue was highly recurrent in patients with progressed fibrosis (54.5\% vs. $45.5 \%, \mathrm{P}=0.02)$. Meanwhile, the infective dose of HCV was higher in sufferers with HP DNA in liver tissue compared to patients with no HP DNA in liver tissue $(9.0 \times 105 \mathrm{vs}$. $0.05 \times 105)$. There hasn't been a relation among the tested bacteria and some factors as age, sex and (LFT) liver function tests while (AFP) $\alpha$-fetoprotein levels did not differ between patients in absence or presence H.pylori DNA.

Conclusion: There was coexistence of HP infection, HCV infective dose and liver fibrosis.

Keywords: HP DNA, HCV, Fibrosis, Liver function, PCR.

\section{Introduction}

There was no cross infection between A, B and hepatitis $\mathrm{C}$ virus which had severe complications from the chronic inflammatory disease of hepatic cirrhosis and hepatocellular carcinoma (HCC) (Butel, 2007). The incidence of the viral infection was about 170-200 million persons worldwide. Egypt has high records of hepatitis $\mathrm{C}$, because of high morbidity and mortality rates, seropositive $\mathrm{HCV}$ antibodies were found in almost twelve blood donors over a hundred patients (El-Zanaty \& Way, 2008).
The sequence of disease differs among sufferers. Many elements as infection duration, gender, steatosis, the immune response of virus, age and alcoholism have been involved in the progress of fibrosis (Caste'ra et al., 2003).

Beside the previous factors, there are others such as genetic factors and heredity or ecological factors as bacterial co-infection (Caste'ra et al., 2006). A relationship between the investigated bacteria (HP) and enterohepatic pathology was found by Magadha's Quiroz \& Santos (2001). 
The tested bacteria (HP) was found to secrete a liver- specific toxin in a cell culture, that causes hepatic necrosis and might damage the in vivo liver parenchyma (Meyer-ter-Venn et al., 2001).

The most common bacterial DNA sequences found in the patients' liver was H.pylori DNA, by using PCR amplification (Nilsson et al., 2001).

The presence of bacterial DNA in liver tissue of hepatitis patients strengthens the theory that the tested bacteria leads to hepatic lesions, cirrhosis and hepatocellular carcinoma (HCC). This hypothesis hasn't been established (Rocha et al., 2005).

Around the world, the correlation between HP infection and severity of liver diseases has been reported. But no decisive data is available in Egypt yet, although this inspection indicated the possible connection between HP DNA with the hepatic pathology among $\mathrm{CHC}$ patients.

This research investigated the propagation and the effect of HP DNA on Diagnostic parameters such as histological, biological and bacteriological in chronic hepatitis C patients of Egypt.

\section{Patients and Methods}

Patients

This research was based on 49 participants. They were mentally and physically capable of answering questionnaire and gave a written consent before the research.

\section{Inclusion criteria}

Diagnosis of two adult patients of both sexes from 20 to 54 years old for 6 months with positive serum HCV RNA by Real time PCR assay, chronic hepatitis and no receiving of treatment during the sampling, with exclusion of patients with HBV, HIV and any indication of cirrhosis. All patients were subjected to the following:

\section{Medical history}

The medical history was taken with considering any liver diseases' risk factors such as exposure to $\mathrm{HCV}$ in surgical wards, dental therapy, blood transfusions, needle injury and I.V.injection.

Physical examination

Focused on the symptoms of hepatitis such as hepatomegaly, jaundice and Abdominal ultrasonography for all patients.

\section{Laboratory investigations}

Fasting venous blood samples $(10 \mathrm{ml})$ were collected by trained laboratory technicians. The blood was let to coagulate and then centrifuged at $10000 \mathrm{rpm}$ for $15 \mathrm{~min}$ to separate the serum then the blood was collected in sterile test tubes separated from the serum and kept at $-20{ }^{\circ} \mathrm{C}$ until used. The following biochemical tests were done for all patients groups and control group: Aspartate aminotransferase (AST), alanine aminotransferase (ALT), total and direct Bilirubin, Albumin, creatinine and glucose concentrations were detected by Beckman CX4 chemistry analyzer (NY, USA, supplied by the Eastern Co.For Eng. \& Trade-Giza, Egypt). Viral infection status (HCV Ab and HBS Ag) were measured using Abbott, Ax yam (USA, Supplied by al Kamal company). Serum AFP level was determined using an enzyme-linked binding protein assay kit.

Quantitation of hepatitis $C$ virus RNA in serum

By using primers and Real Time PCR reagents from Stratagene, Qiagen, USA. Low viremia was defined as viral load lower than 100x103 IU/L, moderate viremia as viral load $100-1000 \times 103 \mathrm{IU} / \mathrm{L}$, and high viremia when viral load > $1000 \times 103$ IU/L (Shaker et al., 2010).

Detection of H.pylori DNA from liver tissues DNA extraction

By using Wizard® SV Genomic DNA Purification System (Promega Corporation, Madison, USA) genomic DNA was extracted from liver tissues. And the DNA quantitation was made using the NanoDrop ${ }^{\circledR}(N D)$. Spectrophotometer (Nano- Drop Technologies Inc., Washington, USA). The extracted DNA was stored in $-20^{\circ} \mathrm{C}$ until used.

\section{PCR amplification}

Helicobacter pylori genesig Standard Kit is designed to have the wide profile and for the in vitro quantification of the specific H.pylori genomes.

\section{Real-time PCR}

A Helicobacter pylori specific primer and probe mix detected through the FAM channel. This mix exploits the so-called TaqMan $\mathbb{}$ 
principle. During PCR amplification, forward and reverse primers hybridize to the H.pylori DNA. A fluorogenic probe consists of a DNA probe labeled with a 5 '-dye and a 3 '-quencher. Also during the amplification, the probe split and the indicator dye and quencher are separated. The increase in fluorescence can be discovered on real-time PCR platforms.

\section{Statistical analysis}

The analysis of continuous variables was made by Mann-Whitney $U$ test. The analysis of categorical data was made by Chi-square and with Yates correction tests. The estimation between the titer of anti-H.pylori and fibrosis was made by Pearson's correlation coefficient. Multivariate analysis was using a logistic model with a gradual method. A P value of $\leq 0.05$ was significant. Statistical analyses were done using Sigma Stat (version 2.03, SPSS Inc., Chicago, IL) and SPSS 6.1J (SPSS Inc., Chicago, IL).

\section{$\underline{\text { Results }}$}

The data of the chronic hepatitis $\mathrm{C}$ patients under study 49 ( 32 male patients and 17 female). The patient's age was $9.9 \pm 7$ (Table, 1 ).

\section{Detection of H.pylori}

There was no correlation between HP DNA in the hepatic tissue of chronic hepatitis $\mathrm{C}$ and hepatic assessments, Alpha-fetoprotein degrees, serum total bilirubin and albumin, prothrombin concentration and platelet count. But there were considerable variations $(\mathrm{P}=0.01)$ in $\mathrm{HCV}$ load. In patients of HCV, the hepatitis $\mathrm{C}$ viral load of patients was directly proportional with Helicobacter pylori infection, as high viral load with HP infected patients while low load in HP free patients. (Table 2).

There wasn't any significant variation statistically between patients with and without Helicobacter pylori in platelet count $(\mathrm{P}=0.89)$, also not in viral RNA degrees in serum among sufferers either with or without HP antibodies $(\mathrm{P}=0.26)$ was reported.

Helicobacter pylori DNA was recorded in $22(44.9 \%)$ hepatitis $\mathrm{C}$ virus patients under study in the Table 3 . There was no correlation between HP DNA in the hepatocytes of chronic hepatitis C sufferers and gender, age, LFT or Alpha-Fetoprotein. Though, significant variation in the degrees of the viral RNA in serum between sufferers with and without H.pylori DNA existed $(\mathrm{P}=0.01)$.

The cases of Helicobacter pylori were more prevalent in chronic hepatitis $\mathrm{C}$ cases with a progressive phase of hepatic cirrhosis12/18 $(66.7 \%)$ than in low phase of liver fibrosis $10 / 31$ (32.3\%). So, there was significant statistical ( $\mathrm{P}$ $=0.02$ ) correlation between HP DNA of hepatic tissue and phases of fibrosis (Table 4).

\section{Discussion}

Many fields have been estimated a correlation between Helicobacterceae specially Helicobacter spp. and hepatic diseases in humans (Zulu et al., 2003 and Tiwara et al., 2006). The higher the propagation of Helicobacterceae coexisted with highly progressive phases of hepatic disorders, they have huge role in chronic persistent hepatitis progression towards fibrosis and hepatocellular carcinoma (Pelican et al., 2004).

Determinants are not completely acknowledged, including those in Hepatitis $\mathrm{C}$ virus cases (Rocha et al., 2005). In this study, DNA of Helicobacter pylori was tested on biopsies of $44.9 \%$ hepatitis C virus Egyptian patients, agrees with previous studies (Caste'ra et al., 2006; Rocha et al., 2005 and Dore et al., 2002).

In our study, About $45 \%$ of the subjected patients of CHC were co-infected with HP DNA. This was assured by El-Masry et al. (2010) and Quiroz et al. (2006) who estimated the relation among HP infection and cirrhosis of hepatitis $\mathrm{C}$ virus sufferers. The goal of the current work has been to measure the influence of HP DNA upon the liver tissue with hepatitis $C$ virus sufferers as responding to Interferon- $\alpha$ and ribavirin therapy.

Helicobacter pylori DNA positive results $(\mathrm{P}=0.02)$ were higher in chronic hepatitis $\mathrm{C}$ cases with advanced phase of hepatic fibrosis $(66.7 \%)$ more than in cases with minimal phase of liver fibrosis $(32.3 \%)$ ). Our result were similar to the study of Caste'ra et al. (2006) in which observations showed that higher propagation of HP DNA in hepatic specimens from fibrotic and non-fibrotic livers. 
TABLE 1. Demographic and laboratory statistics of the studied population ( $n=$ forty nine).

\begin{tabular}{|c|c|c|c|}
\hline \multicolumn{2}{|c|}{ Variable } & \multirow{2}{*}{$\begin{array}{c}\text { No. }(\mathrm{N}=\text { forty-nine }) \\
\text { Thirty-two }\end{array}$} & \multirow{2}{*}{$\begin{array}{c}100 \% \\
65.3\end{array}$} \\
\hline Kind of cox & Men & & \\
\hline Ninu or sex & Women & Seventeen & 34.7 \\
\hline & Mean \pm SD & Minimum & Maximum \\
\hline Age (y) & $39.9 \pm 7.9$ & 20 & 54 \\
\hline Body Math Index & $27.1 \pm 9.5$ & 18 & 45 \\
\hline Aspartate aminotransferase & $66.9 \pm 29.7$ & 22 & 160 \\
\hline Alanine aminotransferase & $64.6 \pm 28.7$ & 34 & 154 \\
\hline Total bilirubin & $1.11 \pm 0.47$ & 0.5 & 2.6 \\
\hline Direct bilirubin & $0.26 \pm 0.16$ & 0.1 & 0.9 \\
\hline Albumin & $3.83 \pm 0.32$ & 3 & 5 \\
\hline Glucose & $99.4 \pm 17.3$ & 70 & 153 \\
\hline Alphafeto protein & $12.9 \pm 13.0$ & 3 & 91 \\
\hline Homoglobin & $12.0 \pm 1.8$ & 9 & 15 \\
\hline $\operatorname{PCR}\left(\mathrm{x} 10^{5}\right)$ & $23480 \pm 113565$ & 0.003 & 740000 \\
\hline $\begin{array}{l}\text { Thyroid stimulating } \\
\text { hormone }\end{array}$ & $3.66 \pm 0.76$ & 2 & 6 \\
\hline Creatine & $0.97 \pm 0.16$ & 0.6 & 1.5 \\
\hline platelet count & $290.2 \pm 75$ & 165 & 450 \\
\hline Alkaline Phosphatase & $116.9 \pm 48.5$ & 5 & 223 \\
\hline Iron salts & $179.7 \pm 58.0$ & 100 & 342 \\
\hline
\end{tabular}

TABLE 2. Evaluation among negative and positive $H$. pylori DNA concerning laboratory findings.

\begin{tabular}{|c|c|c|c|c|c|c|}
\hline \multirow[t]{2}{*}{ Variable } & \multicolumn{2}{|c|}{$\begin{array}{c}\text { Negative H.Pylori DNA } \\
(\text { No. }=27)\end{array}$} & \multicolumn{2}{|c|}{$\begin{array}{c}\text { Positive H.Pylori DNA } \\
\text { (No.=22) }\end{array}$} & \multirow[t]{2}{*}{$\begin{array}{c}\text { MWU } \\
\text { test }\end{array}$} & \multirow[b]{2}{*}{$\mathbf{P}$} \\
\hline & Median & Range & Median & Range & & \\
\hline $\begin{array}{l}\text { Aspartate } \\
\text { aminotransferase }\end{array}$ & 54.0 & $22-160$ & 69.0 & $30-150$ & 1.86 & $\begin{array}{c}0.062 \\
(\mathrm{NS})\end{array}$ \\
\hline $\begin{array}{l}\text { Alanine } \\
\text { aminotransferase }\end{array}$ & 60.0 & $34-154$ & 60.0 & $40-140$ & 0.2 & $0.84(\mathrm{NS})$ \\
\hline Total bilirubin & 1.0 & $0.5-2.5$ & 0.95 & $0.6-2.6$ & 0.9 & $0.37(\mathrm{NS})$ \\
\hline Direct bilirubin & 0.2 & $0.1-0.9$ & 0.2 & $0.1-0.8$ & 0.31 & $0.75(\mathrm{NS})$ \\
\hline Albumin & 4.0 & $3.4-4.5$ & 3.6 & $3-5$ & 2.24 & $0.025(\mathrm{~S})$ \\
\hline Glucose & 100.0 & $80-153$ & 95.0 & $70-141$ & 0.08 & $0.93(\mathrm{NS})$ \\
\hline Alphafeto protein & 10.0 & $3-91$ & 10.5 & $3-27$ & 0.01 & $0.99(\mathrm{NS})$ \\
\hline Homoglobin & 13.0 & $9-15$ & 12.0 & $9-15$ & 0.89 & $0.37(\mathrm{NS})$ \\
\hline $\operatorname{PCR}\left(x 10^{5}\right)$ & 0.05 & $0.003-400$ & 9.0 & $0.009-740000$ & 2.57 & $0.01(\mathrm{~S})$ \\
\hline $\begin{array}{l}\text { thyroid } \\
\text { stimulating } \\
\text { hormone }\end{array}$ & 3.6 & $2-5$ & 4.0 & $2.8-6$ & 1.72 & $\begin{array}{l}0.085 \\
(\mathrm{NS})\end{array}$ \\
\hline Creatine & 0.9 & $0.6-1.5$ & 1.0 & $0.7-1.3$ & 0.72 & $0.47(\mathrm{NS})$ \\
\hline platelet count & 300.0 & $189-450$ & 285.0 & $165-420$ & 0.11 & $0.91(\mathrm{NS})$ \\
\hline $\begin{array}{l}\text { Alkaline } \\
\text { Phosphatase }\end{array}$ & 112.0 & $5-223$ & 103.5 & $45-220$ & 0.23 & $0.82(\mathrm{NS})$ \\
\hline Iron salts & 187.0 & $100-342$ & 165.5 & $100-233$ & 1.73 & $\begin{array}{c}0.084 \\
(\mathrm{NS})\end{array}$ \\
\hline
\end{tabular}


TABLE 3. H. pylori DNA in liver tissues regarding severity of fibrosis.

\begin{tabular}{|c|c|c|c|c|c|}
\hline & & & \multicolumn{2}{|c|}{ H. pylori DNA } & \multirow[b]{2}{*}{ Total } \\
\hline & & & Negative & Positive & \\
\hline \multirow{4}{*}{ Fibrosis stage } & & Count & 21 & 10 & 31 \\
\hline & & $\%$ within $H$. pylori & $77.8 \%$ & $45.5 \%$ & $63.3 \%$ \\
\hline & & Count & 6 & 12 & 18 \\
\hline & High & $\%$ within $H$. pylori & $22.2 \%$ & $54.5 \%$ & $36.7 \%$ \\
\hline \multirow[t]{2}{*}{ Total } & & Count & 27 & 22 & 49 \\
\hline & & $\%$ within $H$. pylori & $100.0 \%$ & $100.0 \%$ & $100.0 \%$ \\
\hline
\end{tabular}

$\mathrm{X} 2=5.45 \quad \mathrm{P}=0.02(\mathrm{~S}) \quad \mathrm{S}=($ significan $)$

Table 4. Correlation in liver tissue among the grades of chronic hepatitis $\mathrm{C}$ and Helicobacter pylori DNA.

\begin{tabular}{|c|c|c|c|c|c|}
\hline & & & \multicolumn{2}{|c|}{ H. pylori DNA } & \\
\hline & & & Negative & Positive & \\
\hline grades of chronic & \multirow{2}{*}{ Minimal, mild } & Count & 21 & 14 & 35 \\
\hline \multirow[t]{3}{*}{$\mathrm{HCV}$} & & \% within Hpylori & $77.8 \%$ & $63.6 \%$ & $71.4 \%$ \\
\hline & & Count & 6 & 8 & 14 \\
\hline & Moderate, severe & \% within Hpylori & $22.2 \%$ & $36.4 \%$ & $28.6 \%$ \\
\hline \multirow[t]{2}{*}{ Total } & & Count & 27 & 22 & 49 \\
\hline & $\%$ within Hpylori & $100.0 \%$ & $100.0 \%$ & $100.0 \%$ & \\
\hline
\end{tabular}

$\mathrm{X}^{2}=1.19 \quad \mathrm{P}=0.27$ (no signification)

High participation of Helicobacter pylori DNA in the cases with progressive phase of fibrosis than minimal phase of it may indicate the HP role in the advance of the chronic viral hepatitis toward hepatocellular carcinoma (Caste'ra et al., 2006).

It was supposed that Helicobacter pylori infection may influence any associated $\mathrm{HCV}$ through the down regulation of the CD4+ (T-Lymphocyte helper) and Tregs (T-Lymphocte regulatory gene) (Shirai et al., 1998). Also, the Incidence of Helicobacter pylori D NA has been revealed in patients with cirrhosis in the liver tissue and occurred more in liver cancer (Rocha et al., 2005 and Chen et al., 2010).

No proof was illustrated to suppose that Helicobacter pylori raises CHC severity, since medical and chemical investigations, specially Alanine Aminotransferase titer, neither change between $\mathrm{HCV}$ patients alone nor those co-infected with HCV and HP (Table 2). Comparing between studied groups was found statistically minor $(\mathrm{P}-\mathrm{value}=0.82$ ). Our results illustrated analogue with published works which stated there wasn't a correlation among the previous factors, HP infection and chronic viral hepatitis (Caste'ra et al., 2006 and Petrenkienë et al., 2004). Many studies have reported hepatitis B virus interference with hepatitis C virus (Jade et al., 2001; Pontius et al., 1993 and Signally et al., 2000). Our research subjected that statistically considerable difference between negative \& positive Helicobacter Pylori DNA groups as well the viral load of hepatitis $C$ virus RNA as shown in Table 3 and Fig. 1, (P-value $=0.01)$ and contrary to, this result doesn't agree with data obtained by Umemura et al. (2007) who mentioned that the HCV RNA titer in sufferers 
with HCV and Helicobacter pylori co-infection was clearly decreased in viral infection alone $(\mathrm{P}=0.013)$, referring HP infection could oppose the viral reproduction.

Till now, the viral-bacterium cascade is still unknown. Further studies, HCV replicon system should be analyzed (Tanaka et al., 2000).

Helicobacter species existed in the hepatic tissue of hepatitis $\mathrm{C}$ virus, and have been related to hepatocellular carcinoma evolution in the non-fibrotic liver (Meyer-ter-Venn et al., 2001; Vakil et al., 2000 and Nilsson et al., 2001).

Majority of patients with Hepatocellular carcinoma are HP carriers, was reported by Rocha et al.(2005). Cirrhotic patients (61-68\%) are HP $(+\mathrm{ve})$ in contrast with $4.5 \%$ hepatitis patients and 3.2\%. This assumes that HP DNA in the hepatic tissue can be a predisposing factor in chronic hepatitis $\mathrm{C}$ virus progression of liver disease.

Since hepatocellular carcinoma wasn't detected, we couldn't estimate the degree and the presence of HP with hepatocellular carcinoma progress. Since there are no researches for the clarification, larger populations of sufferers with $\mathrm{CHC}$ and cirrhosis should be tested.

In our study, the platelet count had no considerable difference among patients with viralbacterium infection compared to the hepatitis $\mathrm{C}$ virus group (P-value $=0.91)$ (Table 2). This dissimilarity of studies have illustrated that the bacterial eradication is associated with a considerable thrombocytosis in idiopathic thrombocytopenia patients (Michel et al., 2004 and Stasi et al., 2005). Even though this study predicts the participation of Helicobacter pylori, an insignificant knowledge was found about the Helicobacter pylori idiopathic thrombocytopenia pathogenesis. Suspicion of Helicobacter pylori involvement in different autoimmune disorders, including idiopathic thrombocytopenia existed (Michel et al., 2004 and Francine \& Venire, 2004). Also, HP might exaggerate the fibrosis and cirrhosis as presented in our study (Chen et al, 2010). So we conclude that this research offers a good study about the correlation among HP DNA and hepatitis $\mathrm{C}$ patients towards fibrosis.

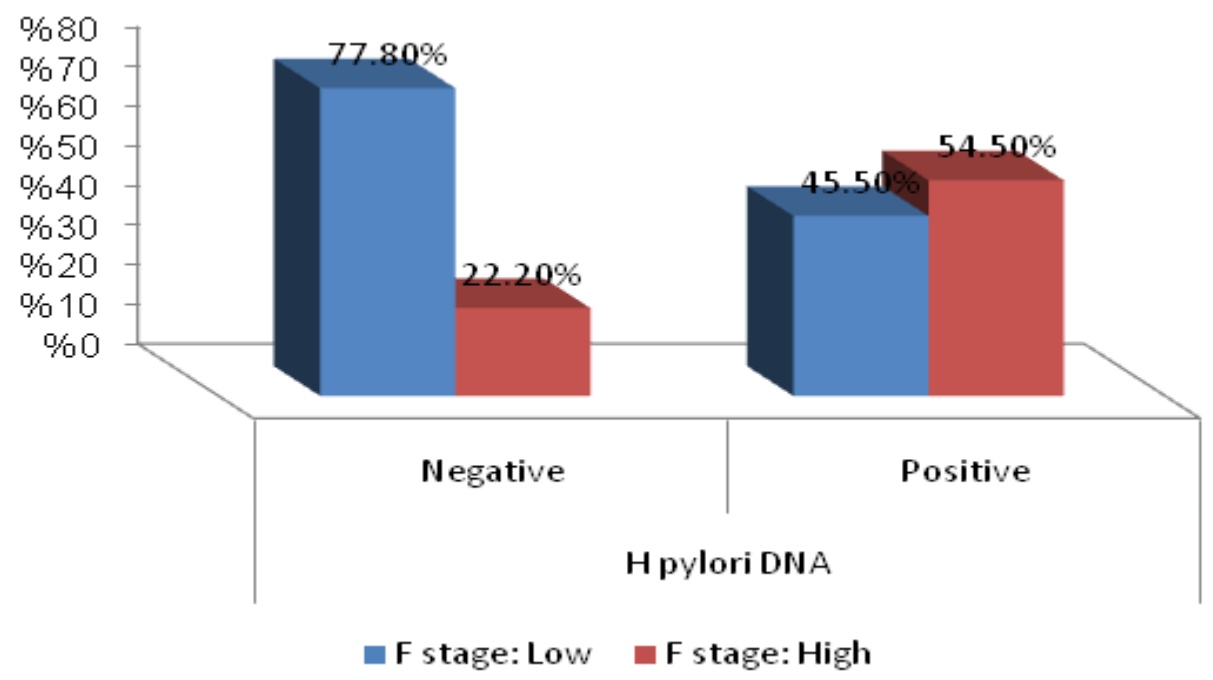

Fig. 1. H.pylori DNA in liver tissues regarding severity of fibrosis. 


\section{References}

Avenaud, P., Marais, A. and Monteiro, L. (2000) Detection of Helicobacter species in the liver of patients with and without primary liver carcinoma. Cancer, 89, 1431-9.

Butel, J.S. (2007) Virology. In: " Medical Microbiology" Brooks, G.F., Carroll, K.C,, Butel. J.S., Mores, S.A., (Ed.), pp. 367-620. New York, McGraw Hill.

Caste'ra, L., Hezode, C., Roudot-Thoraval, F., Bastie, A., Zafrani, E.S. and Pawlotsky, J.M. (2003) Worsening of steatosis is an independent factor of fibrosis progression in untreated patients with chronic hepatitis $\mathrm{C}$ and paired liver biopsies. Gut, 52, 288-92.

Caste'ra, L., Pedeboscq, A., Rocha, M., LeBail, B., Asencio, C. and de Ledinghen, V. (2006) Relationship between the severity of hepatitis $\mathrm{C}$ virus related liver disease and the presence of Helicobacter species in the liver: a prospective study. World J Gastroenterol, 12(45), 7278-84.

Chen, R., Chen, X.P., Lin, Q.Q., Lin, B.L. and Cao, H.J. (2010) Detection of Helicobacter species related genes coding for 16S rRNA in the liver tissue of patients with chronic liver disease. Nan Fang Yi Ke Dа ХиеХие Вао. 30(1), 131-132.

Dore, M.P., Realdi, G., Mura, D., Graham, D.Y. and Sepulveda, A.R. (2002) Helicobacter infection in patients with HCV-related chronic hepatitis, cirrhosis, and hepatocellular carcinoma. Dig. Dis. Sci.47,1638-43.

El-Masry, S., El-Shahat, M.; Badra, G.; Aboel-Nour, M.; Lotfy, M. 2010.Helicobacter pylori and hepatitis $\mathrm{C}$ virus coinfection in Egyptian patients. $J$ . Glob Infect Dis , 2(1), 4-9.

El-Zanaty, F. and Way, A. (2008) Egypt Demographic and Health Survey. [accessed 06.01.11].

Franchini, M. and Veneri, D. (2004) Helicobacter pylori infection and immune thrombocytopenic purpura: an update. Helicobacter, 9, 342-346.

Jardi, R., Rodriguez, F. and Buti, M. (2001) Role of hepatitis B, C, and D viruses in dual and triple infection: influence of viral genotypes and hepatitis $\mathrm{B}$ precore and basalcore promoter mutations on viral replicative interference. Hepatology, 34, 404-10.
Magalhaes-Queiroz, D.M. and Santos, A. (2001) Isolation of a Helicobacter strain from the human liver. Gastroenterology, 121, 1023-4.

Meyer-ter-Vehn, T., Covacci, A., Kist, M. and Pahl, H.L. (2001) Helicobacter pylori activates mitogenactivated protein kinase cascades andinduces expression of the proto-oncogenes c-fos and c-jun. J. Biol. Chem. 2000, 275(21), 16064-72.

Michel, M., Cooper, N., Jean, C., Frissora, C. and Bussel, J.B. (2004) Does Helicobater pylori initiate or perpetuate immune thrombocytopenic purpura? Blood, 103, 890-896.

Nilsson, H.O., Mulchandani, R., Tranberg, K.G., Stenram, U. and Wadstrom, T. (2001) Helicobacter species identified in liver from patients with cholangiocarcinoma and hepatocellular carcinoma Gastroenterology, 120, 323-4

Pellicano, R., Mazzaferro, V., Grigioni, W.F., Cutufia, M.A., Fagoonee, S., Silengo, L. and Rizzetto, M. (2004) Helicobacter species sequences in liver samples from patients with and without hepatocellular carcinoma. World J. Gastroenterol. 10(4), 598-601.

Petrenkienë, V., Vitkauskienë, A., Jonaitis, L., Kupèinskas, L. and Wadström, T. (2004) Detection of Helicobacter spp. In liver biopsy specimens. Acta MedicaLituanica, 11(3), 31-35

Pontisso, P., Ruvoletto, M.G. and Fattovich, G. (1993) Clinical and virological profiles in patients with multiple hepatitis virus infections. Gastroenterology, 105, 1529-33.

Queiroz, D., Rocha, A., Rocha, G., Cinque, S., Oliveira, A. and Godoy, A. (2006) Association between Helicobacter pylori infection and cirrhosis in patients with chronichepatitis C virus. Dig. Dis. Sci. 51(2), 370-3.

Rocha, M., Avenaud, P., Menard, A., Le Bail, B., Balabaud, C. and Bioulac-Sage, P. (2005) Association of Helicobacter species with hepatitis C cirrhosis with or without hepatocellular carcinoma. Gut, 54, 396-401.

Sagnelli, E., Coppola, N. and Scolastico, C. (2000)Virologic and clinical expressions of reciprocal inhibitory effect of hepatitis B, C, and delta viruses in patients with chronic hepatitis. Hepatology, 32, 1106-10. 
Shaker, O., Ahmed, A., Doss, W. and Abdel-Hamid, M. (2010) MxA expression as markerfor assessing the therapeutic response in HCV genotype 4 Egyptian patients. $J$. Viral Hepat. 17, 794-799.

Shirai, M., Arichi, T., Nakazawa, T. and Berzofsky, J.A. (1998) Persistent infection by Helicobacter pylori down-modulates virus-specific CD8+ cytotoxic T cell response and prolongs viral infection. J. Infect. Dis. 177(1), 72-80.

Stasi, R., Rossi, Z., Stipa, E., Amadori, S., Newland, A.C. and Provan, D. (2005) Helicobacter pylori eradication in the management of patients with idiopathic thrombocytopenic purpura. Am. J. Med. 118, 414-419

Tanaka, E., Ohue, C. and Aoyagi, K. (2000) Evaluation of a new enzyme immunoassay forhepatitis $\mathrm{C}$ virus $(\mathrm{HCV})$ core antigen with clinical sensitivity approximating that of genomic amplification of HCV RNA. Hepatology, 32, 388-93.
Tiwari, S., Khan, A., Ibrahim, M., Habeeb, M. and Habibullah, C. (2006) Helicobacter pylori and other Helicobacter speciesDNA in human bile samples from patients with various hepato-biliary diseases. World J. Gastroenterol. 12(14), 2181.

Umemura, T., Muto, H. and Tanaka, E. (2007) AntiHelicobacter pylori seropositivity: Influence on severity and treatment response in patients with chronic hepatitis C. Journal of Viral Hepatitis, 14, 48-54.

Vakil, N., Rhew, D., Soll, A. and Ofman, J.J. (2000) The cost-effectiveness of diagnostic testing strategies of $H$. pylori. Am. J. Gastroentreol. 95,1691-8.

Zullo, A., Hassan, C. and Morini, S. (2003) Helicobacter pylori infection in patients with liver cirrhosis:facts and fictions. Dig. Liver Dis. 35(3), 197-205.

(Received 19/2/2017; accepted 28/5/2017) 


\section{دراسة تأثير إقتران الهيليكوباكتر بيلوري مع فيروس التهاب الكبد C فى بعض المرضى المصريين}

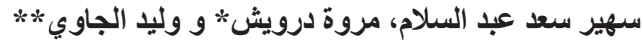

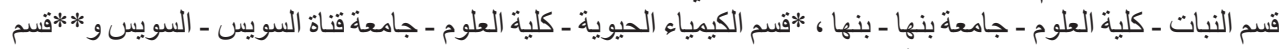
الطب الاستو ائي ـ مركز البحوث لأمر اض الكبد و الطب الاستو ائي ـ القاهرة ـ مصر.

نظرا لوجود كل من التهاب الكبد الوبائي C وكذلك الإصابه بهيليكوباكتر بيلوري في مصر تم ربط ربط علاقية

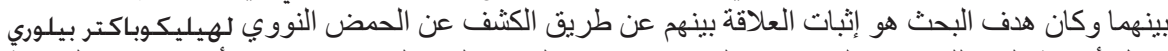

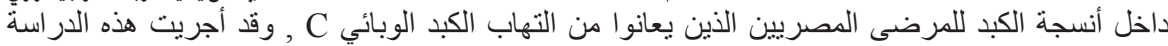

الاستطلاعية على 49 مشاركا.

تم تصميم مجمو عة قياسية من (H.pylori) جينوم لتعيين H.pylori في أنسجة الكبد للمصابين بإلتهاب

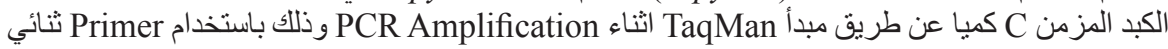

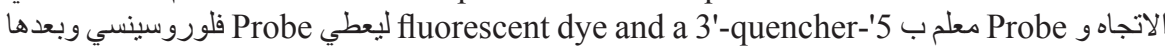

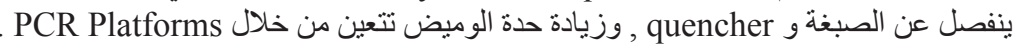

وجد الحمض النووي البكتيري في عينات الكبد لحو الي \%44.9\% من المرضى وكان متكرر بنسبة عالية في

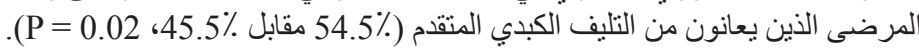

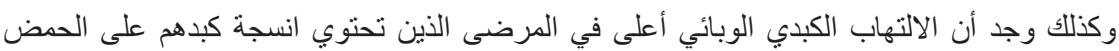

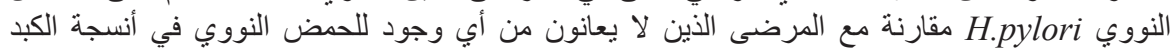

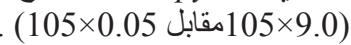

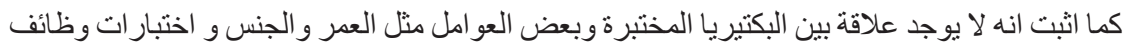

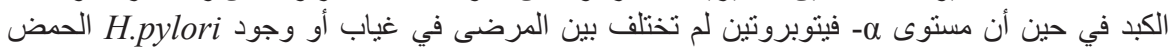

